\title{
Samuel Daniel et le paradoxe de la frontière : "Thames doth out goe / Declined Tybur "
}

\section{Christine Sukic}

\section{(2) OpenEdition}

\section{Journals}

Édition électronique

URL : http://journals.openedition.org/shakespeare/843

DOI : 10.4000/shakespeare.843

ISSN : 2271-6424

Éditeur

Société Française Shakespeare

Édition imprimée

Date de publication : 1 novembre 2005

Pagination : 221-233

ISBN : 2-9521475-1-5

\section{Référence électronique}

Christine Sukic, «Samuel Daniel et le paradoxe de la frontière : « Thames doth out goe / Declined Tybur » », Actes des congrès de la Société française Shakespeare [En ligne], 22 | 2005, mis en ligne le 01 janvier 2007, consulté le 02 mai 2019. URL : http://journals.openedition.org/shakespeare/843 ; DOI : $10.4000 /$ shakespeare. 843 


\section{Shakespeare et l'Europe de la Renaissance}

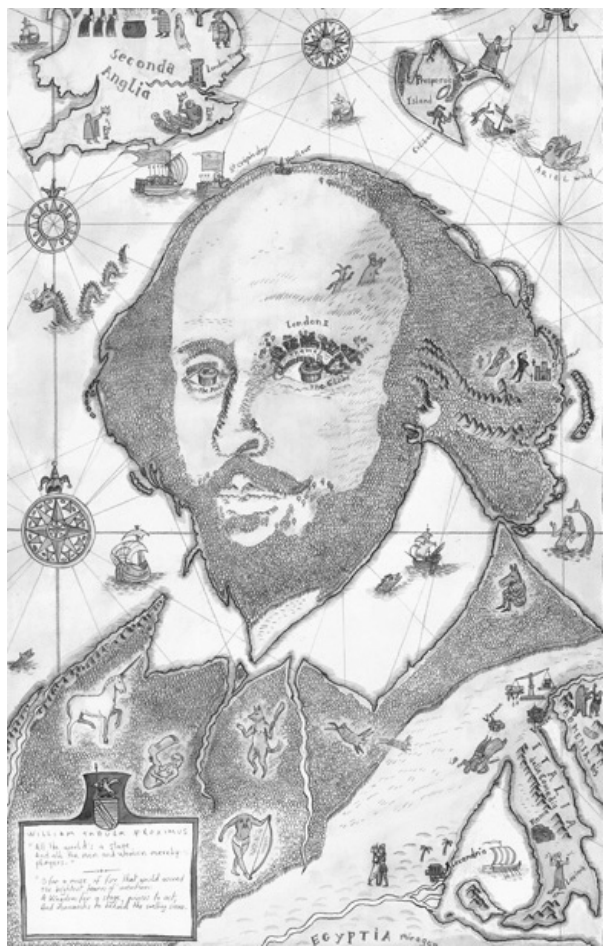

a ctes du Congrès

organisé par la

SOCIÉTÉ FRANÇAISE SHAKESPEARE

les 11,12 et 13 mars 2004

textes réunis par

Pierre KAPITANIAK

sous la direction de

Yves PEYRÉ 


\title{
COMITÉ SCIENTIFIQUE :
}

\author{
Margaret Jones-Davis \\ Jean-Marie Maguin \\ Yves Peyré \\ Pierre Kapitaniak
}

COUVERTURE :

Edouard Lekston, William Tabula Proximus, 2004

conception graphique et logo

Pierre Kapitaniak

CC 2004 Société Française Shakespeare

Institut du Monde Anglophone

Université de Paris III - Sorbonne Nouvelle

http:// univ-montp3.fr/SFS/

5 rue de l’École de Médecine

75006 Paris

ISBN 2-952 1475-1-5

Tous droits de traduction, de reproduction et d'adaptation réservés pour tous les pays 


\title{
SAMUEL D ANIEL ET LE PARADOXE DE LA FRONTIÈRE : « THAMES DOTH OUT GOE / DECLINED TYBUR »
}

\begin{abstract}
Christine SUKIČ
L'œuvre de Samuel Daniel, depuis sa traduction des devises de Paolo Giovio en 1585, jusqu'à sa pastorale dramatique Hymens Triumph en 1615, est entièrement tournée vers la littérature européenne de son temps, notamment italienne et française. Pourtant, sa poésie, son théâtre et son œuvre historique constituent une affirmation incessante de son désir de voir naître un véritable idiome poétique national, même s'il s'est nourri de littératures étrangères. II accomplit ce projet de "défense et illustration " de la langue et de la littérature anglaises par la création d'un locus poétique, qui se superpose au lieu géographique qu'est l'Angleterre, et par son œuvre d'historien, l'écriture historique se confondant avec l'écriture poétique.

Samuel Daniel is well-known as an imitator of Italian and French poetry. He translated Italian works and borrowed from the pastorals of Tasso and Guarini as well as from the French sonneteers of the sixteenth century. And yet, his main concern seems to have been the creation of a national poetical idiom, that would allow England to gain its literary independence from its European neighbours. In his poetry, Daniel constantly reaffirmed the national status of the English language and literature and aimed at creating a poetical locus. This was confirmed by his work as historian of his own country, in both prose and verse.
\end{abstract}

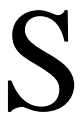

amuel Daniel semble partager avec les autres membres du cercle de la Comtesse de Pembroke la contradiction d'être à la fois entièrement tourné vers la littérature de l'Europe de son époque, en particulier d'Italie et de France, et de s'inscrire en même temps dans un autre parcours, constructif celui-là, qui vise à une « défense et illustration » de la langue anglaise et de sa littérature. Cette défense, en particulier pour Daniel, prend bien souvent la forme d'une contreattaque, comme si la France, mais surtout l'Italie, voulaient imposer leur domination sur ce que Daniel appelle, dans son épître dédicatoire à la Comtesse de Pembroke pour Cleopatra, ses « Northern tunes ${ }^{1}$ » L'Europe, pour Samuel Daniel, pose donc la question de l'identité nationale, qui se forge dans un combat incessant où, comme dans la citation, extraite de cette même préface, que j'ai placée en exergue de cet article, la Tamise devra surpasser le Tibre déclinant.

On le sait, Daniel est à la fois poète et historien, puisqu'il a publié, outre des pièces de théâtre et des recueils poétiques, une

\footnotetext{
1 «To the most noble Lady, the Lady Mary Countesse of Pembrooke», in Certaine Small Workes heretofore divulged by Samuel Daniel one of the Groomes of the Queenes Majesties privie Chamber \& new againe by him corrected and augmented, Printed by I. L. for Simon Waterson, Londres, 1607, consulté dans la base de données de Literature Online (LION).
} 
histoire de l'Angleterre, The Collection of the Historie of England ${ }^{2}$. Mais il me semble que pour lui, il n'y a pas de séparation générique entre l'écriture poétique et l'écriture historique, d'autant plus que son poème narratif, The civile warres betweene the how ses of Lancaster and $Y_{\text {orke }}{ }^{3}$, est, en quelque sorte, une Histoire en vers. Écrire l'Histoire de son propre pays, c'est lui constituer une identité nationale, en imitation d'autres identités nationales européennes, de la même manière qu'écrire des vers, c'est écrire une poésie nationale, qui aura autant de valeur que les poésies nationales d'autres pays européens. Dans les deux cas, il s'agira de venir alimenter la Tamise et de surpasser le débit du Tibre. Dans les deux cas, il s'agira aussi de créer un lieu, à la fois lieu de la nation et locus poétique.

Tout d'abord, je rappellerai brièvement ici les liens qui unissent Daniel à la littérature de l'Europe de la Renaissance, et que l'on peut faire remonter à son amitié avec John Florio, alors qu'ils se trouvaient tous deux à Oxford dans les années 1580 . La première publication de Daniel est une traduction en italien, celle du livre d'emblèmes de Paolo Giovio, publiée à Londres en 1585 sous le titre suivant: The Worthy Tract of Paulus Iovius ${ }^{4}$. On sait aussi que la poésie de Daniel est fortement inspirée des sonnets français et italiens et que son théâtre pastoral emprunte beaucoup à Guarini et au Tasse, mais en ceci, on ne peut pas dire qu'il fasse preuve d'une grande originalité par rapport à ses contemporains anglais. En revanche, un court aperçu des préfaces qu'il a écrites pour ses amis écrivains montre son intérêt pour la traduction et pour les ouvrages d'apprentissage des langues européennes. En effet, sur les huit poèmes dédicatoires qu'il a écrits, cinq précèdent des traductions de l'italien ou du français ${ }^{5}$, un

${ }^{2}$ The Collection of the historie of England. By S. D., Printed by Nicholas Okes, dwelling in Foster-lane for the author, Londres, 1618.

${ }^{3}$ La première édition date de 1595 et ne contient que les quatre premiers livres. L'édition complète paraît en 1609 .

${ }^{4}$ The Worthy tract of Paulus Iouis, contayning a Discourse of rare inuentions, both Militarie and Amorous called Imprese. Whereunto is added a Preface contayning the Arte of composing them, with many other notable devises, Printed for Simon Waterson, Londres, 1585.

${ }^{5}$ Ces traductions sont les suivantes : la traduction anonyme du Pastor fido de Guarini, Il Pastor Fido: or the faithfull Shepheard. Translated out of Italian into English, For S. Waterson, Londres, 1602 ; la traduction de la Sepmaine de Du Bartas par Josuah Sylvester, Bartas his Devine Weekes and Workes translated... by I. Sylvester, H. Lownes, Londres, 1605 ; la traduction de Nennio de Giovanni Battista Nenna par William Jones, Nennio, Or a treatise of Nobility: Wherein is discoursed what true Nobilitie is, with such qualities as are required in a perfect Gentleman, Printed by P. S. for L. Linley and J. Flasket, Londres, 
accompagne le manuel d'apprentissage du français de Pierre Erondelle, The French Garden ${ }^{6}$, et un autre le dictionnaire anglo-italien de Florio, Queen Anna's New World of Words ${ }^{7}$.

Chacun de ces poèmes ${ }^{8}$ est l'occasion pour Daniel de faire l'éloge de l'auteur traduit, ou de montrer l'importance de l'apprentissage du français ou de l'italien. L'œuvre de Du Bartas, traduite par Josuah Sylvester est un trésor inestimable («th'immortall store / Of others sacred lines »). Dans le poème qui précède la première édition des Essais traduits par Florio, Montaigne se voit accorder le titre de Prince : «Prince Montaigne (if he be not more) ». Guarini, lui, est, plus simplement «deare esteemed Guarini », dans le poème qui accompagne la traduction du Pastor fido.

Les liens de Daniel avec la littérature européenne sont réaffirmés par l'auteur lui-même, en particulier lorsque, dans l'épître dédicatoire à Robert Carr qui accompagne The Collection of the Historie of England, dans l'édition de 1618, il montre comment l'idée d'écrire son Histoire de l'Angleterre lui est venue notamment pendant son séjour à l'étranger :

I alledge, that having spent much time of my best understanding, in this part of humane Learning, Historie, both in forraine countries where especially I tooke those notions, as made most for the conduct of businesse in this kind, and also at home, where it hath bene in my fortune (besides conference with men of good experience) to have seene many of the best discourses, negotiations, instructions and relations of the generall affaires of the World : I resolved to make triall of my forces in the contexture of our owne Historie ${ }^{9}$.

\footnotetext{
1595 ; et deux éditions de la traduction des Essais de Montaigne par John Florio, celle de 1603, The Essayes, or Morall, Politike and Millitarie Discourses of Lo: Michaell de Montaigne..., Printed at London by Val. Sims for Edward Blount dwelling in Paules churchyard, et celle de 1613: The Essays, M. Bradwood for E. Blount and W. Barret, Londres.

${ }^{6}$ The French Garden : for English Ladyes and Gentlewomen to walke in. Or, A Sommer dayes labour. Being an instruction for the attayning vnto the knowledge of the French tongue, For Edward White, Londres, 1605.

7 Queen Anna's new World of Words; or, Dictionarie of the Italian and English tongues, collected and newly much augmented by J. F. ... Whereunto are added certaine necessarie rules and short observations for the Italian tongue, M. Bradwood, For E. Blount and W. Barret, Londres, 1611.

${ }^{8}$ Les textes de ces ouvrages ont tous été consultés sur la base de données LION.

9 "Epistle-Dedicatory», The Collection of the History of England. 1612-1618, in The Complete Works in Verse and Prose of Samuel Daniel, éd. Alexander B. Grosart, 5 vol., New York, Russell \& Russell, 1963 [1885], vol. 4, p. 75.
} 
De même, dans son adresse au lecteur, il n'hésite pas à citer ses sources, qui sont bien souvent françaises, et dont il tient à souligner l'importance, parce qu'elles sont porteuses d'une autre perspective : «For forraine businesses (especially with France, where we had most to doe) I have for Authors, Paulus Aemilius, Haillan, Tillet, and others, without whom we cannot truly understand our owne Affayres ${ }^{10}$ ». L'Histoire de l'Angleterre commence donc, pour Daniel, par une « délocalisation ».

Néanmoins, autant il me semble indispensable de montrer, dans cette introduction, ce qui unit Daniel à l'Europe de la Renaissance, et en particulier à sa littérature, autant je pense que ce type de travail pourrait être effectué pour nombre des contemporains de Daniel. Ce qui me paraît plus intéressant, c'est que ce poète adopte bien souvent une rhétorique défensive par rapport à la littérature européenne, comme si cette influence indispensable constituait aussi un danger pour la défense de la littérature anglaise. Daniel a donc une relation ambiguë à l'Europe — une Europe qui se réduit à la France et à l'Italie - qui est pour lui à la fois une source poétique indispensable, mais aussi une rivale.

Malgré toutes les influences reçues, l'Angleterre, dans l'imaginaire du poète, demeure une île, c'est-à-dire une terre isolée du reste de l'Europe. C'est cette caractéristique qui, pour Daniel, semble être la plus importante. Ainsi, dans son Panegyrike Congratulatorie, poème qu'il adresse, en 1603, à Jacques I ${ }^{\text {er }}$ lors de son accession, Daniel montre comment la Grande-Bretagne - et non plus seulement l'Angleterre - est désormais, grâce au monarque, une île à part entière :

...O thou mighty State,

Now thou art all Great-Britaine and no more,

No Scot, no English now, nor no debate ;

No borders but the Ocean and the shore:

No wall of Adrian serves to separate

Our mutuall love ${ }^{11} \ldots$

10 «Certaines advertisements to the reader», ibid., p. 82.

${ }^{11}$ A panegyrike congratulatorie deliuered to the Kings most excellent Maiestie at Burleigh Harrington in Rutlandshire. By Samuel Daniel. Also certaine epistles, with a defence of ryme heretofore written, and now published by the author, Imprinted [by R. Read] for Edward Blount, Londres, 1603. Consulté sur la base de données LION. 
Évidemment, ce poème est surtout une occasion pour Daniel de s'attirer les bonnes grâces du roi, mais ce motif de l'insularité se retrouve dans toute son œuvre, antérieure ou ultérieure. Il y a donc chez ce poète un désir d'ouverture, dans les deux sens, c'est-à-dire un désir de recevoir, et de donner, mais cela implique la nécessité d'une définition géographique du lieu d'où il parle, et donc des limites de ce lieu. On trouve ainsi dans la poésie de Daniel de nombreuses références au lieu qu'est l'Angleterre, ou la Grande-Bretagne, qu'il s'efforce de définir comme un locus poétique, et non pas comme un simple lieu géographique.

Déjà, dans Delia, recueil de sonnets publié pour la première fois en 1592, le lieu même où vit Delia devient source de substance poétique. Évidemment, Daniel tente de créer un locus poétique comme Pétrarque l'avait fait pour les lieux visités par Laure. De la même manière qu'il compare Delia à Laure, et son amour pour elle à celui que Pétrarque portait à sa bien-aimée, Daniel mythifie l'Angleterre, et en particulier le sud-ouest de l'Angleterre, où vit Delia.

Thou canst not dye whilst any zeale abounde,

In feeling harts, that can conceive these lines:

Though thou a Laura hast no Petrarch founde In base attire, yet cleerely Beautie shines.

And I, though borne in a colder clime,

Doe feele mine in ward heate as great, I knowe it :

He never had more faith, although more rime,

I love as well, though he could better shew it.

But I may ad one feather to thy fame,

To helpe her flight throughout the fairest Ile :

And if my penne could more enlarge thy name,

Then shouldst thou live in an immortall stile.

But though that Laura better limned bee,

Suffice, thou shalt be lov'd as well as shee ${ }^{12}$.

On le voit, Daniel se situe dans l'opposition au sud : il ne manque pas une occasion de rappeler que l'Angleterre est un État septentrional, mais que cela ne l'empêche pas de posséder la chaleur et la brillance d'un locus poétique, puisque telle doit être la nature de ce lieu dans ce genre qu'est le sonnet. Il emploie d'ailleurs cette même image dans le Panegyrike congratulatorie, en louant les qualités de son nouveau roi,

\footnotetext{
${ }^{12}$ Sonnet 35 dans l'édition de Sprague, Poems and A Defence of Ryme, éd. Arthur Colby Sprague, Chicago, Londres, The University of Chicago Press, 1965, p. 28.
} 
qui fera briller «this empire of the North», État septentrional certes, mais où l'astre est tout de même source de chaleur.

On observe donc, dans ce recueil, Delia, une ouverture à la poésie européenne, puisque Daniel y revendique la référence à Pétrarque. Il s'inspire aussi de poètes français mais en cela, je le répète, il ne fait pas preuve d'une grande originalité. En revanche, ce qui me semble plus intéressant, c'est que cette ouverture se double d'une fermeture des frontières, et que le caractère insulaire et septentrional du lieu poétique y est loué, comme dans cet autre sonnet :
Drawne with th'attractive vertue of her eyes,
My toucht hart turnes it to that happie cost :
My ioyfull North, where all my fortune lyes,
The levell of my hopes desired most.
There where my Delia fayrer then the sunne,
Deckt with her youth whereon the world smyleth :
Ioyes in that honour which her beautie wonne,
Th'eternall volume which her fame compyleth.
Florish faire Albion, glory of the North,
Neptunes darling helde betweene his armes:
Devided from the world as better worth,
Kept for himselfe, defended from all harmes.
Still let disarmed peace decke her and thee ;
And Muse-foe Mars, abroade farre fostred bee ${ }^{13}$.

L'Angleterre a donc aussi sa Laura. Le soleil n'y brille pas autant que du côté d'Avignon, mais c'est parce que l'île est séparée du monde que la substance poétique y est si riche. L'insularité est donc une nécessité du lieu, du locus, car elle affirme cette séparation du reste du monde. L'isolement au milieu des mers donne au lieu de la poésie un statut particulier, le protégeant et le singularisant. C'est d'ailleurs là un des paradoxes de ces sonnets de Daniel, à la fois italiens et insulaires.

On aurait d'ailleurs pu croire que Daniel, dans son entreprise de mythification du lieu, en profitât, dans son Histoire de l'Angleterre, pour donner à son pays des origines fictionnelles, ce que d'autres historiens n'ont pas hésité à faire. Il rejette au contraire le célèbre mythe utilisé par Geoffrey de Monmouth qui fait remonter la généalogie des rois d'Angleterre à Brutus, et préfère plaider l'incertitude quant à l'origine de son pays :

${ }^{13}$ Sonnet 44 , ibid., p. 32. 
How the beginnings of all people and States were as uncertaine, as the heads of great Rivers [...]. Considering, how commonly they rise from the springs of poverty, pyracie, robbery and violence, howsoever fabulous Writers (to glorifie their nations) strive to abuse the credulity of after ages with heroycall, or miraculous beginnings [...] So that with what credit, the accompt of above a thousand yeares from Brute to Cassevellaunus (in a line of absolute Kings) can be cleared, I doe not see; and therefore will leave it on the booke to such as will bee creditors, according to the substance of their understanding ${ }^{14}$.

En revanche, de la même manière qu'il tente, dans Delia, de redonner à l'Angleterre un statut de lieu poétique, il s'efforce de re-mythifier le Moyen Âge anglais. Ainsi, comme les autres pays européens, l'Angleterre des $\mathrm{XVI}^{\mathrm{e}}$ et $\mathrm{XVII}^{\mathrm{e}}$ siècles ne surgit pas d'une obscurité médiévale, mais d'une incontestable richesse culturelle. C'est d'ailleurs bien ce que défendaient les poètes qui entouraient la Comtesse de Pembroke qui, tout en puisant allègrement aux sources italiennes et françaises, comme Abraham Fraunce, s'efforçaient aussi de re-créer un Moyen Âge anglais mythique. D'où l'utilisation d'un vocabulaire ou de formes archaïques, ou tout du moins d'un archaïsme de fiction, d'un pseudo-archaïsme, préféré au vocabulaire ou aux formes latins.

L'importance de la Comtesse de Pembroke dans la carrière de Samuel Daniel participe aussi de cette mythification du lieu. Comme l'Italie ou la France ont leurs lieux — fleuves ou rivières, villes ou villages mythiques - ainsi l'Angleterre a Wilton House, lieu par excellence de la création poétique. Ainsi, dans la préface à Cleopatra, cette fois dans l'édition de 1611, Daniel évoque ce lieu qui inspire la poésie :

...those notions which at first in me

The, then dilicious Wilton did impresse

That arbor of the Muses grac'd by thee

And which did likewise grace thy worthinesse ${ }^{15}$.

De même, dans l'épître dédicatoire qu'il adresse au Comte de Pembroke pour A Defence of Ryme (1603), Daniel évoque aussi Wilton, véritable école de poésie: «Hauing beene first incourag'd or fram'd thereunto by your most Worthy and Honourable Mother, receiuing the

\footnotetext{
${ }^{14}$ The Complete Works in Verse and Prose of Samuel Daniel, op. cit., vol. 4, p. 86-88.

15 Cleopatra, in Certaine Small Workes Heretofore Divulged by Samuel Daniell... and now againe by him corrected and augmented, Printed by I. L. for Simon Waterson, Londres, 1611. Consulté sur la base de données LION.
} 
first notion for the fomall ordering of those compositions at Wilton, which I must euer acknowledge to haue beene my best School ${ }^{16}{ }$.

Mais Wilton, ce n'est pas seulement la propriété des Pembroke, et le lieu n'évoque pas uniquement pour Daniel son attachement à la Comtesse. Wilton est aussi un lieu poétique anglais par excellence parce que Sidney y a séjourné de nombreuses fois. Or Sidney, à l'époque où écrit Daniel, est la figure par excellence du poète national, prétexte à nostalgie puisque déjà disparu, mais poète national tout de même. Dans l'épître dédicatoire à la Comtesse de Pembroke pour l'édition de 1599 de Cleopatra ${ }^{17}$, Daniel associe Sidney à Spencer pour démontrer la valeur de la poésie anglaise, valeur qu'il démontre par l'égalité avec la poésie italienne, en usant une nouvelle fois du mode comparatif: "Whereby great Sidney and our Spencer might, / With those $P o$-singers being equalled $»$. Si bien que l'on pourrait dire que les références à Wilton, pour Daniel, ne sont pas uniquement poétiques mais aussi politiques. De la même manière, les échanges poétiques avec les nations européennes seront perçues en termes politiques.

La poésie, pour Daniel, est un geste politique mais aussi une geste. Dans la même épître dédicatoire (Cleopatra, 1599), le poète décrit la résistance à l'ennemi, non pas barbarie, mais barbarisme, comme un combat épique, mené d'abord par Sidney :

\footnotetext{
Now when so many pens (like Speares) are charg'd,

To chase away this tyrant of the North :

Grosse Barbarism, whose powre grown far inlarg'd,

Was lately by thy valiant brothers worth

First found, encountred, and provoked forth :

Whose onset made the rest audacious,

Whereby they likewise have so well discharg'd

Upon that hideous beast incroching thus.

And now must I with that pooere strength I have,

Resist so foule a foe in what I may:

And arme against oblivion and the grave,

That else in darknesse carries all away,

And makes of all our honours but a pray.

So that if by my pen procure I shall
}

\footnotetext{
16 Poems and A Defence of Ryme, op. cit., p. 129.

${ }^{17}$ The Tragedie of Cleopatra in The poeticall essayes of Sam. Danyel, Printed by P. Short for S. Waterson, Londres, 1599, consulté en fac-similé sur le site du Schoenberg Center for Electronic Text and Image, University of Pennsylvania (http://dewey.library.upenn.edu / sceti).
} 
But to defend me, and my name to save, Then though I die, I cannot yet die all ${ }^{18}$.

La poésie est donc un combat à mener avec sa plume, devenue arme de guerre. Daniel reprendra maintes fois cette métaphore, notamment dans les préfaces qu'il écrit pour les traductions que j'ai citées plus haut. Ainsi, la traduction de la Sepmaine de Du Bartas par Josuah Sylvester (1605) est un trésor de guerre pris à la France par un acte de chevalerie :

Thus to adventure forth, and re-convay

The best of treasures, from a forraine Coast, And take that wealth wherin they gloried most, And make it Ours by such a gallant pray, And that without in-justice; doth bewray The glory of the Worke, that we may boast Much to have wonne, and others nothing lost By taking such a famous prize away.

Daniel utilise également souvent la métaphore de l'étranger à qui, par la traduction, l'on accorde la citoyenneté du pays. Montaigne, par l'intermédiaire de Florio, sera « as free, as if borne here ». De la même manière, grâce à William Jones, Giovanni Battista Nenna devient sujet anglais : "Here dost thou bring (my friend) a stranger borne / To be indenized with us, and made our owne. » Quant à l'importation de mots étrangers dans la langue anglaise, pour laquelle Daniel emploie encore la même métaphore de la citoyenneté, cette fois du langage, elle ne doit se faire que par acte de parlement, comme il le montre dans le paragraphe qui conclut $A$ Defence of Ryme:

... we alwayes bewray our selves to be both unkinde, and unnaturall to our owne native language, in disguising or forging strange or unusuall wordes, as if it were to make our verse seeme an other kind of speach out of the course of our usuall practise, displacing our wordes, or investing new, onely upon a singularitie: when our owne accustomed phrase, set in the due place, would expresse us more familiarly and to better delight, than all this idle affectation of antiquitie, or noveltie can ever doe. And I can not but wonder at the strange presumption of some men that dare so audaciously adventure to introduce any whatsoever forraine wordes, be they never so strange ; and of themselves as it were, without a Parliament, without any consent, or allowance, establish them as Free-denizens in our language. But this is but a Character of that perpetuall revolution that never remaine the same, and we must heerein

18 Ibid. 
be content to submit our selves to the law of time, which in few yeeres wil make al that, for which we now contend, Nothing ${ }^{19}$.

Il y a donc identité entre résistance politique à l'intrus, et expression poétique de la langue anglaise. On voit tout de même, dans les derniers mots de l'ouvrage, que Daniel a une grande conscience de l'aspect changeant et instable de la langue et de la poésie nationales — il a aussi une conscience aiguë de l'instabilité en général dans son œuvre historique, d'ailleurs. Il possède aussi une certaine distance par rapport au langage métaphorique qu'il emploie.

Cette définition de la poésie comme geste politique dans l'œu vre de Daniel permet de mieux comprendre d'autres aspects de son œuvre ou de sa personnalité, notamment son attachement au Comte d'Essex, héros national, ou plutôt figure rêvée d'un héros national qui aurait une dimension mythique et pourrait ainsi permettre à l'Angleterre de se mesurer aux autres nations. De la même manière, Daniel, comme d'autres écrivains essexiens, reporte son attachement pour le Comte, après la mort de celui-ci, sur le Prince Henry, porteur de nouveaux espoirs pour le royaume. Comme d'autres Essexiens, Daniel adopte aussi, après 1603, une veine nostalgique qui lui fait prononcer l'éloge de la reine Élisabeth, figure monarchique qui s'inscrit dans une Europe guerrière, une Europe des conflits, garantissant non seulement l'unité politique du pays, mais aussi son unité poétique. Pourtant, dans son Panegyrike congratulatorie, Daniel faisait l'éloge du nouveau prince, ne se référant à Élisabeth que de manière furtive, sans même la nommer ( And give us leave if we / Rejoyce and mourne, that cannot without wrong / So soone forget her we enjoy'd so long»). Malgré cette affirmation - passage obligé du genre, mais dont le développement, compte tenu des circonstances, aurait été malvenu — Daniel va surtout mettre l'accent sur l'unité nouvellement trouvée du royaume, tout en rappelant l'autre unité déjà effectuée par les ancêtres, celle des York et des Lancastre, ce qui lui permet au passage de signaler l'existence de son poème The Civil Wars. L'unité interne prévient le conflit interne, mais pas nécessairement celui qui peut surgir à l'extérieur des limites de l'île :

Time altred hath the forme, the meanes, and brought

The State to that proportion'd evennesse,

${ }^{19}$ Poems and A Defence of Ryme, op. cit., p. 158. 
As 'tis not like againe 'twill ever come

(Being us'd abroad) to draw the sword at home.

L'image de la proportion du royaume est d'ailleurs utilisée aussi dans A Defence of Ryme, texte que Daniel avait également dédié à Jacques I ${ }^{\text {er }}$, et dans lequel il fait aussi l'éloge de «the wonderfull Architecture of this state of England». Deux ans plus tard, avec Philotas (1605), pièce dont on sait qu'elle valut à Daniel d'être convoqué devant le Privy Council, car elle constituait un hommage posthume à peine voilé du comte d'Essex, Daniel s'adresse au Prince Henry et fait le constat de la fin de l'âge d'or de la poésie, celle de la période élisabéthaine :

And know, sweet Prince, when you shall come to know,

That tis not in the pow'r of Kings to raise

A spirit for Verse that is not borne thereto,

Nor are they borne in every Princes dayes:

For late Eliza's raigne gave birth to more

Then all the Kings of England did before.

And it may be, the Genius of that time

Would leave to her the glory in that kind,

And that the utmost powers of English Rime

Should be within her peacefull raigne confin'd :

For since that time, our Songs could never thrive,

But laine as if forlorne; though in the prime

Of this new raising season, we did strive

To bring the best we could unto the time $\mathrm{e}^{20}$.

Il est évident que Daniel fait ici le reproche à Jacques I ${ }^{\text {er }}$ de ne pas être capable de donner à son royaume une identité poétique comme avait pu le faire Élisabeth, même s'il affirme qu'il n'est pas dans le pouvoir des princes de le faire. Le reproche se fait à mots couverts. Six ans plus tard, dans l'épître à la Comtesse de Pembroke pour Cleopatra (1611), Daniel récidive puisque, après s'être de nouveau référé à Sidney, il parle de la gloire de la poésie anglaise, encore une fois au passé :

That influence had Elizaes blessed peace

Peculiar to her glory as it spread

That sacred flame of many, and th'increase

Did grace the season, and her honored

And if the same come now extinguished

By the distemprature of time, and cease

${ }^{20}$ The Tragedy of Philotas (1605), in The Whole Works of Samuel Daniel Esquire in Poetrie, Printed by Nicholas Okes, for Simon Waterson, Londres, 1623. Consulté sur la base de données LION. 
Suffice we were not yet behind the rest, But had our part of glory with the best.

On voit également que Daniel se situe toujours dans la comparaison avec les autres nations. Si l'Angleterre a eu son heure de gloire poétique, cela signifie en premier lieu que sa poésie avait autant de valeur que celle des autres pays d'Europe.

La relation avec l'Europe de la Renaissance, pour Daniel, s'inscrit donc, comme pour beaucoup d'autres écrivains de son temps, tout d'abord dans un geste d'ouverture, et dans un mouvement de réception des poètes et de leurs œuvres. Il y a, on l'a vu également, un désir de fermeture afin d'éviter l'invasion de ce qu'il nomme, dans le Panegyrike congratulatorie, "these forren sinnes we entertaine", expression que l'on doit comprendre également dans sa dimension politico-religieuse. Mais je pense que Daniel est aussi extrêmement ambigu dans sa relation à l'altérité européenne. Même si la fermeture permet d'enrayer l'invasion et la contamination, le poète se rend compte aussi que l'ouverture peut être nécessaire pour que l'Angleterre, comme il le dit, puisse aussi donner autant qu'elle a reçu. C'est cela qui lui donnerait son statut de nation poétique à part entière. C'est ainsi, que, dans le poème dédicatoire à la Comtesse de Pembroke pour Cleopatra (dans l'édition de 1611, mais on retrouve la même idée dans les éditions précédentes), il en appelle à une ouverture des confins de l'île, afin que la Tamise puisse enfin montrer que son débit surpasse celui du Tibre et même qu'elle arrive jusqu'au Tibre :

O that the Ocean did not bound our stile Within these strict and narrow limits, so, But that the musique of our well tund Ile Might hence be heard to Mintium arme \& Po, That they might know how far Thames doth out goe Declined Tybur, and might not contemne Our Northern tunes, but now another while Receiue from vs more then we had from them Or why may not some after comming hand Vnlock these limits, open our our confines, And breake a sunder this imprisoning band T'inlarge our spirits, and let out our designes Planting our roses on the Apinines, And to Iberus, Loyre and Arue to teach That we part glory with their, and our land Being match forworth, comes not behind in speech Let them produce the best of all they may Since Rome left bearing, who bare more the men 


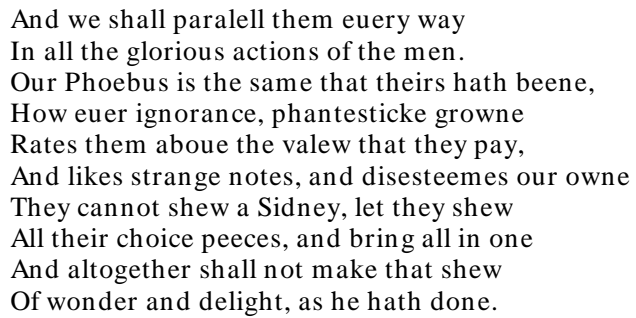

À la fin de la citation, on remarque encore des vers qui se rapportent à Sidney, et qui veulent démontrer la supériorité de celui-ci sur ses contemporains européens. Il est donc évident que la relation de Daniel à l'Europe de son temps se fonde en premier lieu sur la conscience, et même le désir, de l'insularité et de l'isolement, ce qui peut paraître paradoxal pour cet auteur tant féru de culture humaniste. La relation à l'Europe se situe donc dans une définition paradoxale des frontières, à la fois fermées, de fait, par des mers qui protègent, mais qui clôturent aussi, et ouvertes, afin que, idéalement, s'établissent des allers-retours, des passages du continent vers l'île, et de l'île vers le continent. La frontière est la condition même du passage : sans frontières en Europe, le passage n'existe pas. Daniel, par cette définition paradoxale, est assez emblématique de la littérature d'un pays qui se nourrit de tout ce qui se publie et s'accomplit dans l'Europe de son temps, mais dont les représentants prennent également conscience qu'ils sont en train de constituer une œuvre nationale. En même temps, et cela est particulièrement évident dans cette dernière citation, Daniel sait bien que le paradoxe de la frontière tient aussi dans le fait que son ouverture ne se fait que dans un sens. À l'époque donc où il écrit ces vers, la Tamise peine à arriver jusqu'au Tibre, déclinant ou non.

Christine SUKIČ Université de Bourgogne 